\& Noble, 1966). This observation indicates that nuclear programming is influenced by amino acid supply.

Baliga, B. S., Pronczuk, A. W. \& Munro, H. N. (1968). J. molec. Biol. 84, 199.

Elwyn, D. (1969). In Mammalian Protein Metabolism, vol. 4, ohapter 37. Ed. by Munro, H. N. New York: Academio Press, Ino. (in the Press.)

Kenney, M. A., Roderuck, C. E., Arnrich, L. \& Piedad, F. (1968). J. Nutr. 95, 173.

Munro, H. N. (1968). Fed. Proc. 27, 1231.

Munro, H. N. \& Goldberg, D. M. (1964). In The Role of the Gastro-Intestinal Tract in Protein Metabolism, p. 189. Ed. by Munro, H. N. Oxford: Blackwells Scientific Publications.

Pronczuk, A. W., Baliga, B. S., Triant, J. W. \& Munro, H. N. (1968). Biochim. biophys. Acta, 157, 204.

Winick, M. \& Noble, A. (1966). J. Nutr. 89, 300.

Wurtman, R. J. (1969). In Mammalian Protein Metabolism, vol. 4, chapter 36. Ed. by Munro, H. N. Now York: Academio Press, Inc. (in the Press.)

\section{Assessment of Protein Requirements by Nitrogen Balance}

By D. S. Mrrur (Queen Elizabeth College, London W.8) and P. R. PAYNE (London School of Hygiene and Tropical Medicine, London W.C.1)

During the last 100 years, published estimates of the requirements of adult man for protein have fallen from $120 \mathrm{~g}$./day to around $30 \mathrm{~g}$./day. Early estimates were intended, for example by Voit, to be used as dietary standards for workers and were based on recorded intakes of labourers. However, the tradition soon arose that liberal allowances of protein in the diet were essential for the maintenance of mental and bodily vigour, and as a protection against disease. Subsequent research has failed to establish the need for protein over and above that necessary to replace inevitable losses from the tissues and to provide for growth, and thus the criterion of nitrogen balance has come to be generally adopted as an indication of dietary adequacy.

A factorial method for calculating protein requirements will be described. An addition is made of the losses of nitrogen from the body by all routes including urine, faeces, skin, and where appropriate the products of conception, and milk. To these are added calculated nitrogen gains during growth. Allowance can be made for possible variations between individuals, to provide a total nitrogen requirement that can be expressed in terms of an ideal perfectly utilized protein.

Our understanding of the dependence of protein quality on amino acid composition now has a quantitative basis, and other factors that influence the utilization of dietary proteins have been studied and evaluated. In particular the interrelationship between energy and protein metabolism will be examined in view of its importance to the world food problem.

The utilizable protein content of diets can be estimated, and evidence will be presented that man can survive in apparent good health on diets that provide sufficient to meet his estimated needs for nitrogen balance. No claim is made that such diets are culturally acceptable or that higher levels of protein are necessarily detrimental; merely that they confer no known benefit.

During the next 30 years the world's population will double and so will mankind's total nutrient requirements. The lowered estimates for protein allowances do not in any way diminish the magnitude of the task of meeting this growing demand, nor do they represent a lowering of dietary standards, but they should be seen as directing our efforts towards the production of more palatable foods of all kinds rather than searching for some apparently easier solution to the problem by increasing the supply of specific nutrients such as protein.

\section{Protein Nutrition and Enzymes}

By J. C. Wathriow and Joan M. L. Stephen. (Medical Research Council Tropical Metabolism Research Unit, University of the West Indies, Kingston, Jamaica)

In this paper we deal mainly with studies that have been made in man, because this Symposium is concerned with human protein nutrition.

One way of looking at the relationship between protein nutrition and enzyme activity is to regard enzymes as proteins whose specific enzymic activity serves as a natural label or marker. It is not, of course, strictly accurate to equate the activity of an enzyme with its amount. The two things may well be different in vivo, but when assays are made in vitro, under so-called optimum conditions, it is probably reasonable to take activity as a measure of amount.

In studies on human subjects measurements have most often been made on serum or plasma for obvious practical reasons. Enzymes that are found in the plasma must have been synthesized elsewhere; sometimes they are specific for a particular organ or tissue. Examples of plasma enzymes that are decreased in malnutrition with their probable tissues of origin are pseudocholinesterase (acylcholine acyl-hydrolase, EC 3.1.1.8) (liver), alkaline phosphatase (orthophosphoric monoester hydrolase, EC 3.1.3.1) (bone), amylase and lipase (pancreas) (Waterlow, 1969).

In theory a fall in the amount of a circulating enzyme, as measured by its activity, could result 
either from a decreased rate of synthesis in the organ in which the enzyme originates, or from an increased rate of catabolism. The available evidence on protein metabolism indicates that a deficiency of protein has a more direct effect on the synthetic rate than on the catabolic rate, and that if the catabolic rate is affected at all, it is decreased rather than increased (Kirsch, Frith, Black \& Hoffenberg, 1968; James \& Hay, 1968). Therefore it seems a reasonable hypothesis that changes in enzyme concentration may give information about changes in rates of synthesis in the parent tissue.

Measurements of serum enzymes have usually been made from a rather empirical point of view, as corroborative evidence of the existence of protein deficiency. The question of the functional effect, if any, of the enzyme changes has been a secondary one. For pseudocholinesterase we do not even know what the physiological function of the enzyme is. The measurements would, nevertheless, be of great practical value if it could be shown that they provide particularly sensitive indices of the state of protein nutrition. Very few studies, however, have been made with this objective.

From a physiological or functional point of view it is important to distinguish between the effects of a low protein intake and the effects of protein depletion-in other words, between adaptation and breakdown. There is a large literature on adaptive enzyme changes in animals, but very little has been done in man, presumably because of the difficulty of measuring these changes in the blood. It has recently been shown that in the malnourished human infant, as in the protein-depleted rat, the activity of amino acid activating enzymes (the synthetases) in the liver is increased, and that of one of the urea-cycle enzymes, argininosuccinate lyase, is decreased (Stephen \& Waterlow, 1968). The adaptive nature of these changes is obvious.

Long-continued protein depletion leads eventually to death. Presumably this must be preceded by enzyme changes that are pathological because they result from breakdown of the cellular machinery. It is well recognized in general pathology that some serum enzymes, e.g. aminoacyltransferases, isocitrate and lactate oxidoreductases, may be greatly increased as a result of tissue necrosis (Waterlow, Cravioto \& Stephen, 1960; McLean, 1962). However, these effects are not characteristic of protein deficiency, except perhaps as a terminal event. Other changes that have been described and that may be classified as 'breakdowns' are the excretion of abnormal amino acid metabolites in children with kwashiorkor (R. G. Whitehead, 1964), and a decrease in oxidative phosphorylation in the livers of malnourished children, particularly when the liver is fatty (Waterlow, 1961).
Studies of this kind may provide a better understanding of the biochemical lesions in the severely malnourished organism, but of much greater importance than these terminal events is the problem of defining the borderline between physiological adaptation and pathological breakdown. This has a direct bearing on the question of how much protein is needed to maintain health.

J. M. L. S. is seconded to the Department of Health and Social Security.

James, W. P. T. \& Hay, A. M. (1968). J. clin. Invest. 47, 1958.

Kirsch, R., Frith, L., Black, E. \& Hoffenberg, R. (1968). Nature, Lond., 217, 578.

McLean, A. E. M. (1962). Lancet, ii, 1292.

Stephen, J. M. L. \& Waterlow, J. C. (1968). Lancet, i, 118.

Waterlow, J. C. (1961). Proc. Roy. Soc. B, 155, 96.

Waterlow, J. C. (1969). In Mammalian Protein Metabolism, vol. 3, chapter 27. Ed. by Munro, H. N. New York: Academic Press Inc. (in the Press).

Waterlow, J. C., Cravioto, J. \& Stephen, J. M. L. (1960). Advanc. Prot. Chem. 15, 131.

Whitehead, R. G. (1964). Clin. Soc. 26, 271 \& 279.

\section{Protein Nutrition and Wound Healing}

By J. S. Garrow. (Medical Research Council and Department of Obstetrics, Royal Free Hospital, Liverpool Road, London N.1)

In states of severe protein deficiency wounds do not heal well. An extreme example is shown in children with kwashiorkor; in these children even the normal skin losses are not made good by regeneration of new skin, and consequently, in those regions subject to abrasion, such as the buttocks and the flexures of the limbs, the skin is very fragile and may break down completely. In less extreme cases the skin is thin and atrophic, and tends to flake off easily (Waterlow \& Scrimshaw, 1957). There is evidence both in the proteindepleted rat (Waterlow, 1959; Waterlow \& Stephen, 1968) and in the malnourished child (Garrow, 1957) that protein synthesis becomes increasingly concentrated in the metabolically active tissues like the liver and that skin and muscle are relatively neglected.

After severe tissue destruction, such as extensive burns, there is a marked catabolic reaction. A daily protein intake of more than $20 \mathrm{~g}$. of protein nitrogen and $3500 \mathrm{cal} . / \mathrm{m} .{ }^{2}$ is required to achieve nitrogen equilibrium in such patients 1-2 weeks after being burned. Controls or convalescent patients need only 3-7g. of protein nitrogen $/ \mathrm{m}^{2}$ (Sorroff, Pearson \& Artz, 1961). On the other hand, the protein loss after uncomplicated surgery is very little greater than that after calorie restriction in a normal subject (Abbott \& Albertsen, 1963). Probably the catabolic reaction that has been 